\title{
Smoke aerosol properties and ageing effects for northern temperate and boreal regions derived from AERONET source and age attribution
}

\author{
T. Nikonovas, P. R. J. North, and S. H. Doerr \\ Geography Department, College of Science, Swansea University, Singleton Park, Swansea, SA2 8PP, UK \\ Correspondence to: T. Nikonovas (tadas.nik@gmail.com)
}

Received: 17 December 2014 - Published in Atmos. Chem. Phys. Discuss.: 5 March 2015

Revised: 15 June 2015 - Accepted: 23 June 2015 - Published: 17 July 2015

\begin{abstract}
Particulate emissions from wildfires impact human health and have a large but uncertain effect on climate. Modelling schemes depend on information about emission factors, emitted particle microphysical and optical properties and ageing effects, while satellite retrieval algorithms make use of characteristic aerosol models to improve retrieval. Ground-based remote sensing provides detailed aerosol characterisation, but does not contain information on source. Here, a method is presented to estimate plume origin land cover type and age for AERONET aerosol observations, employing trajectory modelling using the HYSPLIT model, and satellite active fire and aerosol optical thickness (AOT) observations from Moderate Resolution Imaging Spectroradiometer (MODIS) and Along Track Scanning Radiometer (AATSR). It is applied to AERONET stations located in or near northern temperate and boreal forests for the period 2002-2013. The results from 629 fire attributions indicate significant differences in size distributions and particle optical properties between different land cover types and plume age. Smallest fine mode median radius $\left(R_{\mathrm{fv}}\right)$ are attributed to plumes from cropland and/or natural vegetation mosaic $(0.143 \mu \mathrm{m})$ and grassland $(0.157 \mu \mathrm{m})$ fires. North American evergreen needleleaf forest emissions show a significantly smaller $R_{\mathrm{fv}}(0.164 \mu \mathrm{m})$ than plumes from Eurasian mixed forests $(0.193 \mu \mathrm{m})$ and plumes attributed to the land cover types with sparse tree cover - open shrubland $(0.185 \mu \mathrm{m})$ and woody savannas $(0.184 \mu \mathrm{m})$. The differences in size distributions are related to inferred variability in plume concentrations between the land cover types. Significant differences are observed between day and night emissions, with daytime emissions showing larger particle sizes. Smoke is predominantly scattering for all of the classes with median single
\end{abstract}

scattering albedo at $440 \mathrm{~nm}$ (SSA(440)) values close to 0.95 except the cropland emissions which have an SSA(440) value of 0.9. Plumes aged for 4 days or older have median $R_{\mathrm{fv}}$ larger by $\sim 0.02 \mu \mathrm{m}$ compared to young smoke. Differences in size were consistent with a decrease in the Ångström Exponent and increase in the asymmetry parameter. Only an insignificant increase in $\operatorname{SSA}(\lambda)$ with ageing was found.

\section{Introduction}

Vegetation fires are estimated to emit $\sim 2.0 \mathrm{Pg}$ of carbon per year into the atmosphere (van der Werf et al., 2010), influencing air quality, weather and climate (Bevan et al., 2009; Langmann et al., 2009). Particulate matter emissions adversely affect human health and mortality rates (Johnston et al., 2012), and have a substantial but very uncertain effect on the Earth's radiative budget (Bond et al., 2013). Climate model intercomparison (Myhre et al., 2013) indicates little agreement in simulated magnitude and sign of direct radiative forcing attributed to biomass burning emissions. Smoke plumes are difficult to observe, characterise and represent in climate models because they contain chemically and microphysically complex particles that evolve during their atmospheric lifetimes. Improving the characterisation of emission factors, aerosol optical properties, mixing effects and microphysical processes in modelling schemes were identified as key directions narrowing the uncertainties and reducing model and observational biases (Koch et al., 2009; Bauer et al., 2010; Bond et al., 2013). 
Characterisation of smoke aerosols is a fundamentally difficult problem because of the dynamic nature of combustion particle formation and evolution. Particulate emission from open biomass burning consists of organic matter, soot carbon and trace inorganic elements. Different chemical species are not discretely separate, but are internally mixed (Reid et al., 2005a). Smoke particle size distributions are typically bimodal with the bulk of mass concentrated in the fine mode (aerosols 0.1 to $1 \mu \mathrm{m}$ in diameter). Particle production rates, the proportions of different chemical species, particle size distributions, mixing state and hence optical properties of the particles vary greatly depending on the fuel type and moisture, a ratio of flaming versus smouldering combustion, fire intensity, and meteorological conditions at the time of emission (Reid et al., 2005a, b; Janhäll et al., 2010, and references therein).

The complexity of the parametrisation increases with ageing processes. Emitted smoke particles are lofted to altitudes ranging from hundreds to thousands of metres, frequently above the planetary boundary layer (Kahn et al., 2008; Val Martin et al., 2010), and in some cases to the lower stratosphere (Damoah et al., 2006). During the lifetime of several days to weeks plumes can be transported on regional (Colarco et al., 2004) or intercontinental (Damoah et al., 2004; Dirksen et al., 2009) scales.

Most of the changes occur within minutes up to a few hours after emission. Above the flaming zone in cooling plumes particles grow rapidly in size and mass by condensation and coagulation. During the first few hours the particle distribution volume median radius has been reported to increase by up to $\sim 60 \%$ (Hobbs et al., 1996; Abel et al., 2003; Calvo et al., 2010; Akagi et al., 2012). Hobbs et al. (1996) measured a growth in volume median radius from 0.125 to $0.19 \mu \mathrm{m}$ in $2 \mathrm{~h}$ for a large and intense prescribed burn in North America. Near-source condensation of low pressure vapour organics and secondary production of inorganic and organic particulate matter are thought to increase smoke particle size by up to $\sim 10 \%$ (Reid et al., 1998). The rate of coagulation is approximately proportional to the square of particle concentration (Lee and Chen, 1989) and is, therefore, highest near to the source. In highly concentrated plumes, however, coagulation can be important on the timescales of days. Particles continue to grow on these timescales, but at a much lower rate (Radke et al., 1995; Reid et al., 1998; Capes et al., 2008). In addition, water uptake by particles can be significant, in particular at higher relative humidity and for particles with higher amounts of soluble material. Inferred hygroscopic growth factors suggest an increase in particle size by up to $\sim 15 \%$ (Magi and Hobbs, 2003; Rissler et al., 2006). The above particle growth processes enhance smokescattering efficiency. A number of studies report increases in a ratio of scattering extinction to total extinction, single scattering albedo $(\operatorname{SSA}(\lambda))$ in ageing plumes (O'Neill et al., 2002; Abel et al., 2003; Eck et al., 2009).
Northern temperate and boreal forest fires are generally large and intense, with significant contribution of smouldering combustion. Plumes tend to be less absorbing with larger particles than African savanna or Amazonian forest emissions, and exhibit large variability in retrieved properties (Dubovik et al., 2002; Eck et al., 2003). Inferred large particle sizes could be attributed to significant smouldering phase burning, inefficient combustion in very intense flaming fires and accelerated coagulation rates in highly concentrated plumes (Hobbs et al., 1996; Reid et al., 2005a). Even larger particles, with $R_{\mathrm{fv}}$ of $\sim 0.25 \mu \mathrm{m}$, have been observed in aged plumes originating from strongly smouldering combustion of peat fuels (Nakajima et al., 1999; Eck et al., 2003, 2009).

Observation and retrieval of smoke particle properties by remote sensing is challenging because of particularly high spatial and temporal variability in plume occurrence and evolution. Satellite remote sensing provides global and continuous measurements of Aerosol Optical Thickness (AOT) with improving accuracy and between-sensor agreement (Kinne et al., 2003; Kokhanovsky et al., 2010; de Leeuw et al., 2013; Holzer-Popp et al., 2013). However, while methods based on UV absorption or multi-angle retrieval offer the potential to resolve further aerosol properties, (Torres et al., 2007; Kahn et al., 2009; Dubovik et al., 2011), the presence of variable background reflectance over land surfaces makes routine operational retrieval of aerosol absorption problematic, especially at low optical thickness. Accordingly, many retrieval schemes make use of a priori knowledge of properties of characteristic aerosol types within retrievals.

Ground-based Aerosol Robotic Network (AERONET) sun and sky photometers (Holben et al., 1998), located worldwide, provide more robust aerosol measurements. The observations are less affected by the surface reflectance component and are not limited to one or a few view angles. Retrieved aerosol optical and physical properties are fundamental in determining dominant aerosol types for various regions (Dubovik et al., 2002; Lee et al., 2010; Giles et al., 2012) and have become a benchmark for validating satellite observations (Kokhanovsky et al., 2010; Holzer-Popp et al., 2013). AERONET aerosol characterisations have been derived by taking average values from a set of stations assumed to be representative to a certain region or aerosol type. This approach approximates complexities and variability in aerosol properties, but it does not exploit some of the information contained in individual AERONET observations. For example a record from stations located at or near boreal forest is likely to include observations of smoke of various age and origin. Several studies used atmospheric transport modelling and satellite data to determine the source and age for a set of AERONET smoke observations, focusing on individual burning events (O'Neill et al., 2002; Eck et al., 2009; Dahlkötter et al., 2013). Sayer et al. (2014) subdivided sets of AERONET stations representing biomass burning regions into near source and distant ones to explore the ageing effects on optical and microphysical properties. These studies stress 
the need for smoke plume source and age-resolved analysis methods establishing particle properties for different emission sources and long-term ageing effects.

This study addresses this research gap by improving the characterisation and ageing effects of smoke plumes typically attributed to northern temperate and boreal forests. A new method is presented here allowing the estimation of age and source for AERONET aerosol observations. The method is applied with a focus on two aims. The first is to determine smoke particle microphysical and optical properties for emissions from different vegetation types. Explicit source attribution offers additional information content compared to region-based approaches (Dubovik et al., 2002; Giles et al., 2012; Sayer et al., 2014) and could partly address the large variability in aerosol properties characteristic to the boreal forests. The second aim is to explore changes in particle properties occurring in plumes over several days of ageing, complementing existing studies (Radke et al., 1995; Reid et al., 1998; Capes et al., 2008; Eck et al., 2009) with independent estimates based on an alternative method and larger sample.

\section{Data and methods}

The source and age estimation for AERONET smoke observations was achieved by using an air parcel trajectory model and satellite active fire and AOT observations. For all of the selected AERONET smoke observations described in Sects. 2.1 and 2.1.1, a set of air parcel back trajectories ending at a range of altitudes was generated using the HYSPLIT model as specified in Sect. 2.3. Coinciding satellite active fire (Sect. 2.2) and AOT observations (Sect. 2.4) along the trajectories were used as inputs into the decision tree outlined in Sect. 2.5 and Fig. 4, estimating source and age for the AERONET observations.

\subsection{AERONET data}

The analysis is based on AERONET Level 2.0 version 2 inversion data products. AERONET CIMEL radiometers are calibrated and continuously monitored, and data products are cloud screened and undergo robust standardised processing (Holben et al., 2006) which enables quantitative comparative analysis. Direct solar extinction measurements provide columnar AOT at several wavelengths ranging from 340 to $1640 \mathrm{~nm}$. Combined direct sun and diffuse sky radiance measurements at four wavelengths $(440,676,879$ and $1020 \mathrm{~nm}$ ) are best-fitted with a radiative transfer model effectively retrieving columnar aerosol size distribution, spectral complex refractive index, $\operatorname{SSA}(\lambda)$, Ångström Exponent (AE), Absorption Ångström Exponent (AAE), phase function and precipitable water content (Dubovik and King, 2000; Dubovik et al., 2006). Retrieved aerosol optical properties and size distributions are in agreement with indepen- dent in situ aerosol measurements (Haywood et al., 2003; Johnson et al., 2009) and have well-defined uncertainties (Dubovik et al., 2000; Holben et al., 2006). The accuracy of optical properties retrieval is increased during moderate and high aerosol-loading conditions. Level 2 inversions contain SSA retrievals only at AOT(440) levels of 0.4 or higher. AERONET uncertainty for individual SSA retrievals in these cases is approximately 0.03 (Dubovik et al., 2000). Particle fine mode volume median radius has an uncertainty of $0.01 \mu \mathrm{m}$, the spread of the fine mode particle distribution 0.06 . Estimated uncertainty in asymmetry parameter ranges from 0.015 at AOT(440) to 0.04 at AOT(1020) (Dubovik et al., 2000; Sayer et al., 2014). Size distribution parameters and optical properties discussed throughout this study are consistent with the definitions and units described in Holben et al. (2006).

\subsubsection{Data selection}

This study uses data from AERONET stations positioned within or in proximity to the Northern boreal and temperate forests. All available level 2 data with AOT(440) level $\geq 0.4$ from the stations located north of $45^{\circ}$ latitude in North America and Asia (Fig. 1) and collected at any time from the year 2002 through 2013 were selected. European observations were excluded because of higher background AOT levels and more likely mixing of smoke plumes with urban and industrial aerosol. Temporal extent of the study was constrained by the start date of MODIS data availability from both platforms Terra and Aqua in early 2002. AOT records from the selected AERONET stations indicate generally low aerosol background levels with sharp spikes in aerosol loading occurring during the burning season lasting from late spring to early autumn. The pattern suggests that the majority of level 2 retrievals at AOT(440) levels of $\geq 0.4$ ) is a record of biomass burning plumes. Notably, this study is not fully inclusive or exclusive to the Northern forest emissions both in terms of vegetation type or geographic extent. Plumes transported to the selected AERONET locations from areas extending beyond the region of interest and attributed to a range of land cover types have been included in the analysis.

Severe burning seasons in 2004 and 2005 in Alaska caused very high $\operatorname{AOT}(\lambda)$ values $\sim(2-5)$ recorded at Bonanza Creek AERONET station. The very large $(0.2-0.25) R_{\mathrm{fv}}$ values retrieved during these events were attributed to peat fuel combustion (Eck et al., 2009). The method used in this study could not establish ageing properties for these plumes because of a large number of active fires and persistently elevated AOT levels in the region. As a result, Bonanza Creek observations for August in 2004 and 2005 have been excluded from the analysis. 


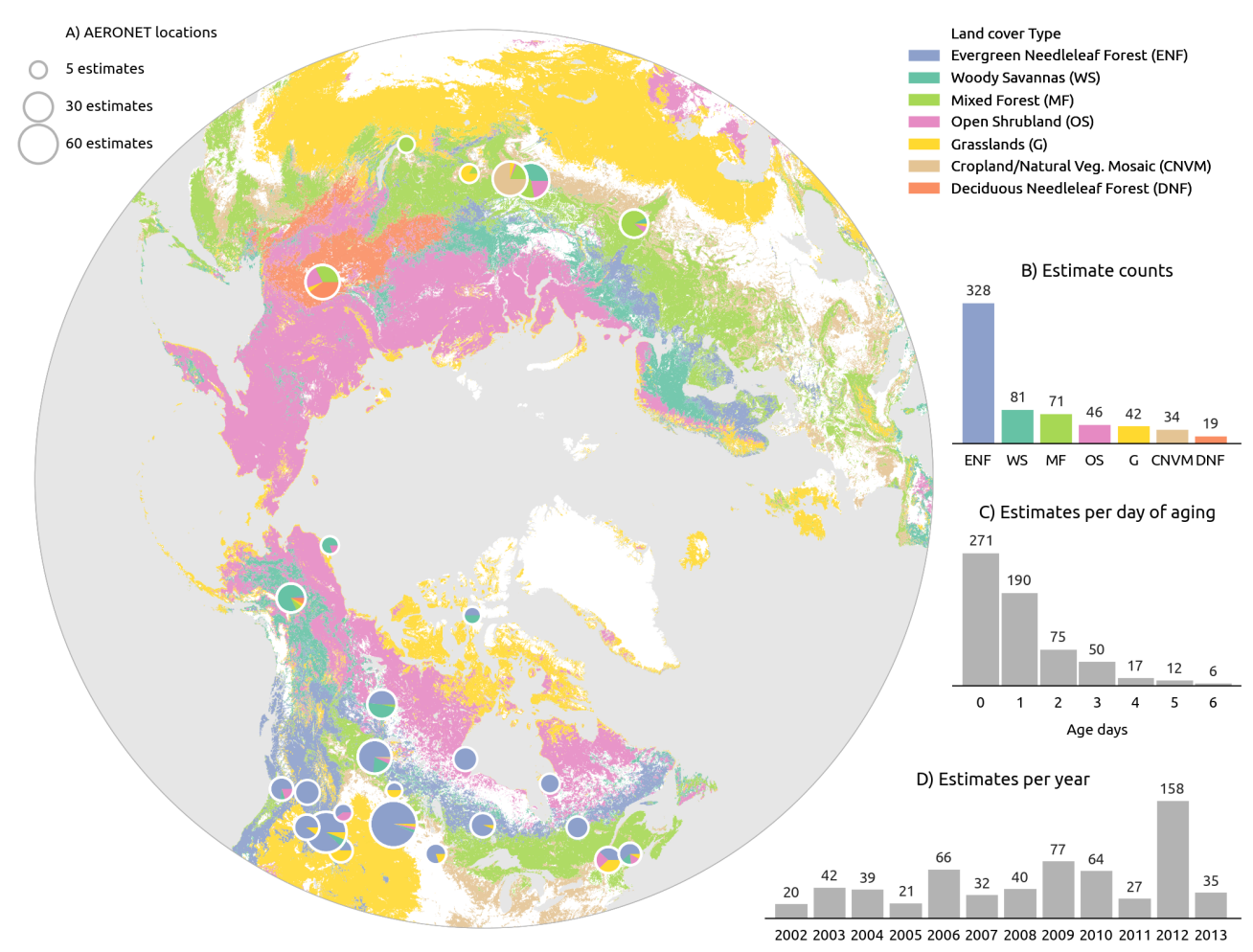

Figure 1. (a) study area, land cover types examined and locations of AERONET stations used. MODIS MCD12C1 land cover data products were employed with classes defined by the International Geosphere Biosphere Programme classification system (Loveland and Belward, 1997). Pie charts inside the circles indicate the origin land cover type of plumes observed at the AERONET stations as estimated in this study. (b-d) show total estimate counts per source land cover type, smoke age per day of ageing and year.

\subsection{Active fire data}

As a proxy for fire activity during the period analysed, the MODIS fire location data set MCD14ML produced by the University of Maryland and provided by NASA Fire Information for Resource Management System was used. The data set contains active fire detections from Terra and Aqua platforms with information of the hotspot location, brightness temperature at MODIS bands 21 and 31, fire radiative power and detection confidence (Giglio et al., 2003).

\subsubsection{Fire data processing and selection}

Fire inventories compiled for Alaska (Stocks et al., 2002) and Canada (Kasischke et al., 2002) indicate that very large fires are not numerous, but account for the majority of the total area burned. Stocks et al. (2002) found that fires larger than $100 \mathrm{~km}^{2}$ represented more than $80 \%$ of total area burned. Following this only large wildfire events which were likely to be strong emission sources were considered in the analysis. To identify such fires MODIS individual hotspots with $80 \%$ or more detection confidence were agglomerated into fire events using the Density-Based Spatial Clustering (DBSCAN) algorithm (Ester et al., 1996). DBSCAN clustering was performed merging individual fire detections into a sin- gle fire object if at least two were found closer together than $10 \mathrm{~km}$ in space and $24 \mathrm{~h}$ in time. The objects were iteratively formed by adding any fire points found within the search radius from all of the fire detections belonging to the cluster (Fig. 2). Identified fire events were considered as large and selected for the analysis if the event duration was more than $48 \mathrm{~h}$, and the spatial bounding box including all points belonging to the event was larger than $100 \mathrm{~km}^{2}$.

\subsubsection{Fire and emission source land cover type}

The emission source land cover type for each of the fire events was determined using MODIS MCD12C1 annual land cover type data products, which employ 17 different land cover classes defined by the International Geosphere Biosphere Programme (Loveland and Belward, 1997). Initially, the land cover type was identified for each of the active fire pixels within a fire event from a grid value given in the $\mathrm{MCD} 12 \mathrm{C} 1$ product from the corresponding year. The land cover value occurring most often (mode) was used as a land cover type identifier for the fire event. This was done for all of the years except 2013 for which MCD12C1 is unavailable and the 2012 product was used instead. 


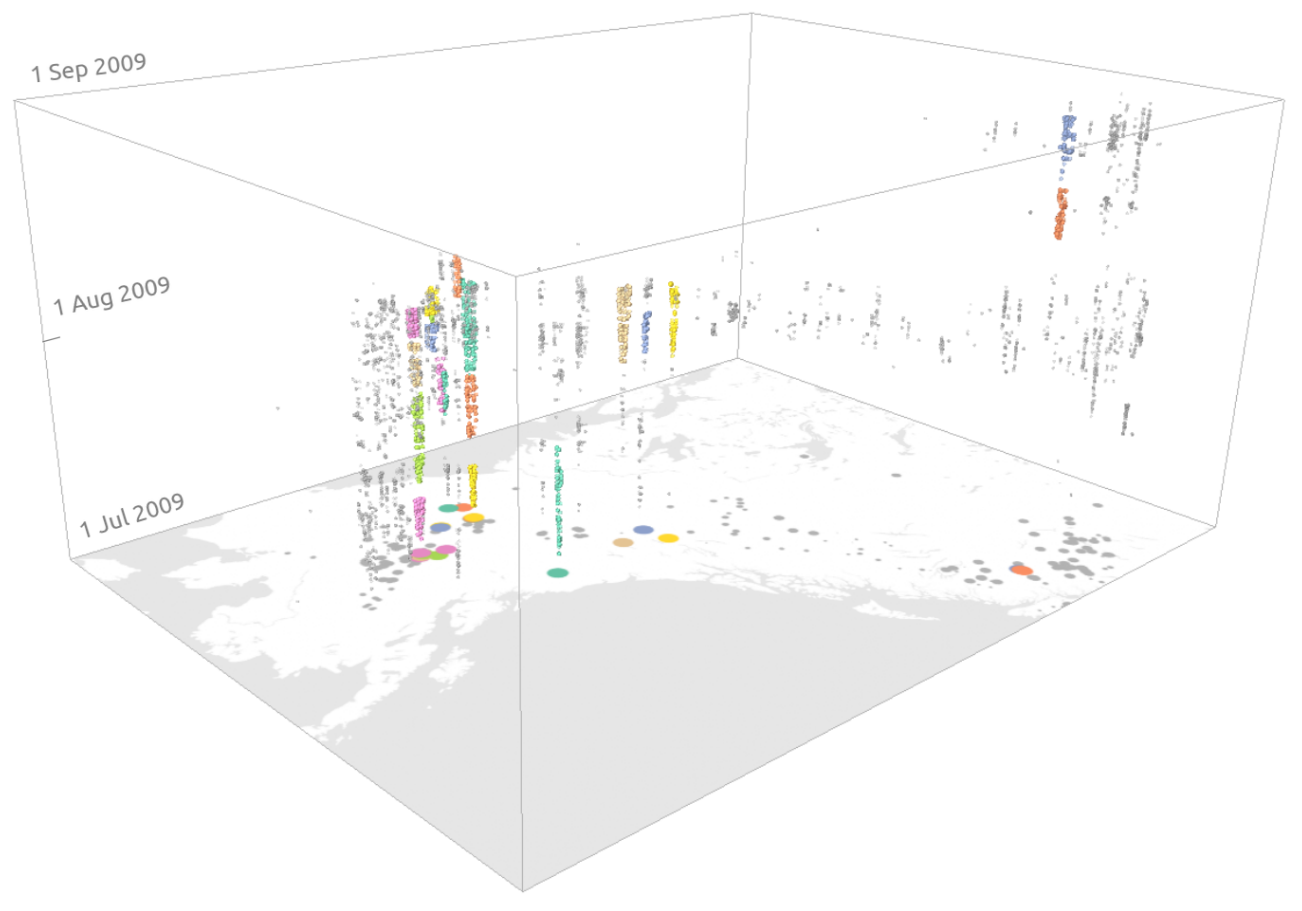

Figure 2. An illustration of the DBSCAN fire pixel segmentation method. Individual MODIS active fires in north-west Canada, Alaska and the north-western USA observed during July-August (vertical axis) in 2009. Colours show separate, large fire objects used in the analysis. Grey fire pixels were removed as described in Sect. 2.2.1.

\subsection{Back trajectories}

To link AERONET observations with source regions and to identify the likely smoke transport pathways, air mass trajectories were computed with the HYSPLIT (Hybrid SingleParticle Lagrangian Integrated) model (Draxler and Rolph, 2003). The HYSPLIT model was run using the Global Data Assimilation System (GDAS) meteorological archive data for the available 2005-2013 period and The National Center for Environmental Prediction and The National Center for Atmospheric Research (NCEP/NCAR) reanalysis data for 2002-2004. For each of the studied AERONET elevated AOT observations (AOT at $440 \mathrm{~nm}$ above 0.4 ) 7 day back trajectories with $1 \mathrm{~h}$ temporal step were generated starting at 16 elevations ranging from 500 to $12000 \mathrm{~m}$ : at $500 \mathrm{~m}$ intervals below 4000 and at $1000 \mathrm{~m}$ intervals above $4000 \mathrm{~m}$. The uncertainty in the individual trajectories was assessed, estimating HYSPLIT Model numerical integration and meteorological data resolution errors. The first was estimated by computing back trajectory and then forward trajectory from the back trajectory's end point. The error was assumed to be half of the horizontal and vertical distance between the initial start and the final end points. The resolution error and resultant divergence in flow field was determined generating a grid of $27(3 \times 3 \times 3)$ back trajectories beginning around the initial start point, with horizontal and vertical offsets given by the estimated numerical error.

\subsection{Satellite AOT}

The two independent satellite AOT data products used are based on observations from (1) The Moderate-Resolution Imaging Spectrometer (MODIS) sensors on-board Terra and Aqua platforms and (2) Along Track Scanning Radiometer (AATSR) sensors flown in succession on ERS2 and ENVISAT satellites. While the method can readily be extended to include further satellite data, the role here is to confirm model tracking of plume transport from source to AERONET, rather than to add additional information on aerosol properties. The MODIS collection 5.1 data set M*D04_L2 is based on the dark target retrieval scheme (Kaufman and Tanre, 1998; Levy et al., 2009) and AATSR_SU on the algorithm developed at Swansea University (North, 2002; Bevan et al., 2012), modified under the ESA Aerosol Climate Change Initiative (CCI) (HolzerPopp et al., 2013; de Leeuw et al., 2013). Both data products provide interpolated AOT at $550 \mathrm{~nm}$ with $10 \mathrm{~km} \times 10 \mathrm{~km}$ pixel size at nadir, which is doubled at the edge of swath for MODIS and increase only negligibly for AATSR. Because of the wider view angle and two sensors operational at the same time, The MODIS data set has greater spatial coverage and temporal resolution. The algorithms perform well compared to AERONET AOT observations. Validation studies suggest RMSE from 0.1 to 0.2 , and little bias between AERONET and both satellite AOT retrieval schemes (Levy et al., 2010; Holzer-Popp et al., 2013). The product 


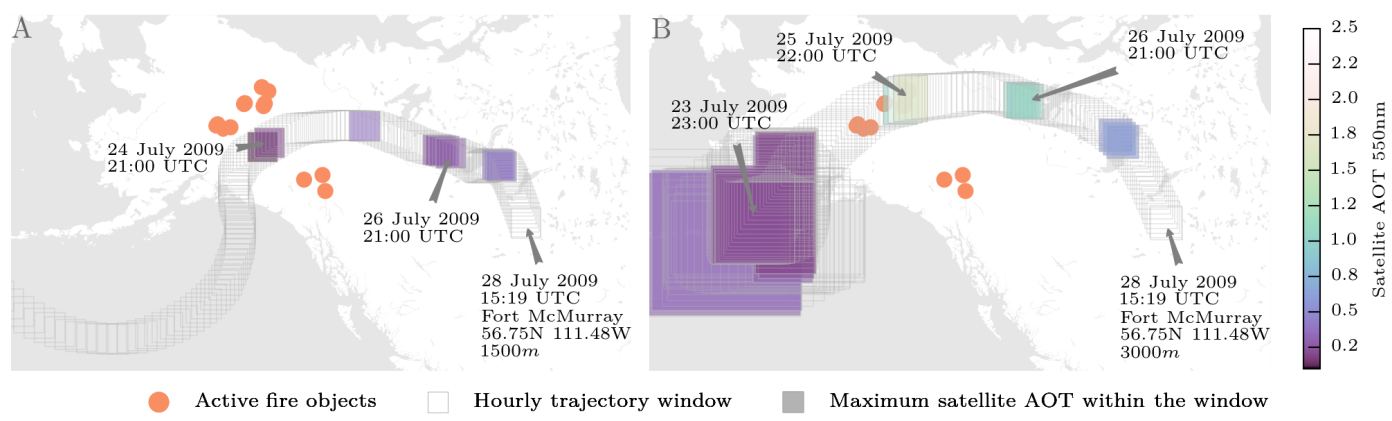

Figure 3. Two 7-day back trajectories ending at Fort McMurray AERONET station and coinciding fire and Satellite AOT observations. (a) trajectory ending at $1500 \mathrm{~m}$ altitude does pass close to active fire objects but satellite AOT remains low. (b) trajectory ending at $3000 \mathrm{~m}$ altitude passes close to the fire objects followed by a sudden increase in observed AOT, indicating the source and age of the AERONET smoke observation.

validations and RMSE as a measure are biased towards low AOT conditions, which constitute the vast majority of the observations. Discrepancies are larger for the aerosol loadings $($ AOT $(440) \geq 0.4)$ analysed herein. Estimated MODIS AOT one sigma expected error bounds increase linearly with AOT $\pm(0.05+0.15 \%$ AOT $)$. AATSR_SU algorithm retrieves AOT only up to 2.0 , meanwhile MODIS M*D04_L2 product contains AOT values up to 5.0. Notably, the algorithms do not estimate AOT over opaque plumes near the source and often reject bright dense smoke as cloud or bright surface (Livingston et al., 2014).

\subsection{Age and source estimation}

Smoke source attribution for AERONET observations was performed by finding coinciding satellite AOT and fire event observations along the generated trajectories and identifying candidate plume pathways. Starting at an AERONET station and an observation time, for each trajectory level spatiotemporal queries were performed, finding any satellite AOT and fire event observations falling within the trajectory domains at hourly steps (Fig. 3). The location and size of spatial search windows at each time step was given by the trajectory uncertainty analysis. Identified AOT observations and proximity to large fire events served as inputs into the decision tree. A trajectory was selected as a candidate if the conditions shown in Fig. 4 were satisfied. When several candidate trajectories were selected, the trajectories were ranked according to the potential fire source size and satellite AOT values observed after the trajectory had passed the source. Finally, the highest ranked candidate was identified as the source and age estimate.

\subsection{Statistical methods}

Error bars and uncertainties on the quantities stated represent $95 \%$ confidence intervals derived using the bias-corrected non-parametric bootstrap methods (Efron, 1993). During the resampling error was modelled as normally distributed
AERONET uncertainty given as 1 standard deviation. The medians of two populations are identified as significantly different if the bootstrapped $95 \%$ confidence interval on difference in medians agree in sign.

\section{Results and discussion}

From a total of 1337 AERONET observations processed, age and source were determined for 629 . The majority of the identifications are for smoke of up to 1-2 days of age, and only $6 \%$ are for plumes older than 4 days (Fig. 1c). The method employed was limited to the tracking of highly concentrated free tropospheric plumes emitted from fires larger than $100 \mathrm{~km}^{2}$ and the results are representative of such events. The sampling bias is particularly severe for very old attributions as only very dense continental superplumes can be observed after several days of ageing. However, fire inventories (Stocks et al., 2002; Kasischke et al., 2002) indicate that large burning events form the dominant mode of burning in boreal and temporal forests. The results of our study suggest that the large plumes are accountable for at least $45 \%$ of AERONET AOT $(440) \geq 0.4$ ) observations in the region.

\subsection{Emission source}

The most frequent emission source land cover type determined was North American evergreen needleleaf forest (ENF) constituting more than half of all estimates (Fig. 1b). The dominance could indicate larger and more intense fires characteristic to North American forests compared with Eurasian boreal regions (de Groot et al., 2013), but this may be caused by uneven spatial distribution of the AERONET stations. Emissions attributed to woody savannas and open shrubland were split between the continents. All mixed forest plumes represent Eurasian fires. Sample size inconsistencies and uncertainty in source attribution should be considered when evaluating the results. Distributions for classes with a small number of estimates exhibit multimodality (Fig. 5) 


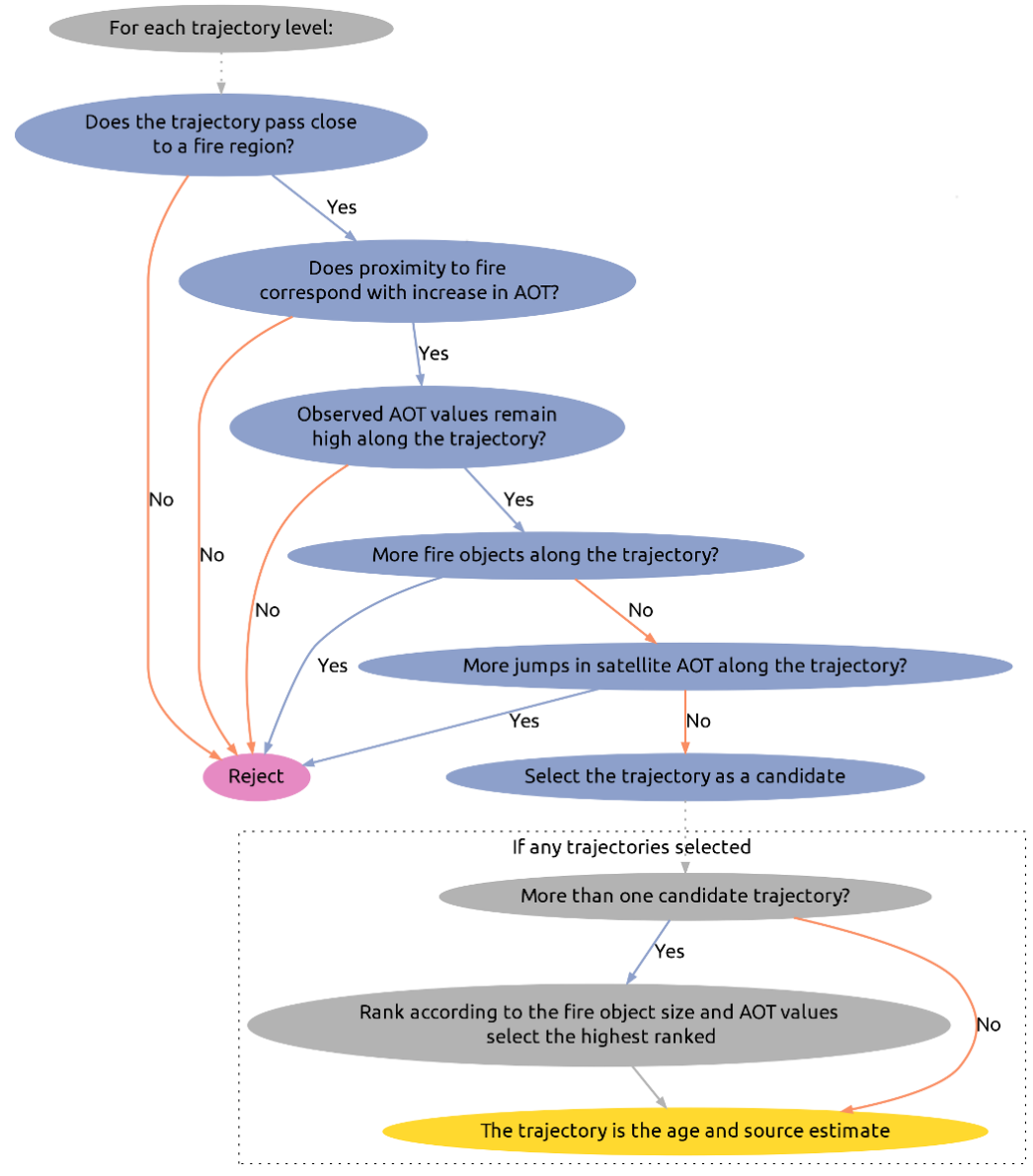

Figure 4. The decision tree used to identify potential smoke source and age. For every AERONET observation back trajectories arriving at different altitudes are tested against the conditions defined in the main part of the decision tree. Any trajectories identified as potential candidates are ranked (lower part of the diagram), identifying a single source and age estimate for the AERONET observation.

and thus their summary metrics should be treated with caution. The source estimates presented here have uncertainties at several levels. Hyer and Reid (2009) found that MODIS land cover type products were only accurate in $\sim 88 \%$ of the cases analysed. In addition, only the dominant land cover type for a given fire is considered here ignoring varying proportions of included grids attributed to different vegetation and intra-grid mixing. Finally, there is likely some unquantified uncertainty in the back trajectory analysis and source age attribution presented here. Despite these limitations the emerging patterns suggest meaningful differences between the plumes attributed to the land cover types discussed.

Plumes show variability in particle concentrations, as indicated by the maximum satellite AOT value along the determined trajectory. The estimate is only an indication of initial plume concentrations because of limitations retrieving AOT over optically thick plumes and large uncertainties associated with high AOT retrievals. However, the highest AOT values are typically found within hours from the source, and therefore are better indicators of the initial plume con- centrations than the downwind AERONET AOT retrievals. Pooled plume concentration estimates seen in Fig. 5d exhibit bimodality. The bulk of all plumes are relatively less dense, with maximum AOT values lower than 3.5. Approximately a quarter of the plumes indicate extreme optical thickness with maximum AOT values above the 3.5 value and often close to or at MODIS saturation value of 5.0. If this interesting feature is not introduced by sampling biasses or satellite AOT retrieval artefacts, it may indicate two distinct emission modes.

Grassland and cropland emissions are distinctively less optically thick, in agreement with observations that flaming grass and shrub fires are less intense and produce less particles than forest fires (Reid et al., 2005a). Notably, Eurasian mixed forest plumes are predominantly in the extremely concentrated group, open shrubland and wooded savannas emissions shared between the continents show clear bimodality, meanwhile North American ENF plumes are primarily less optically thick with a smaller proportion of very dense plumes. Satellite observations and fire inventories suggest 

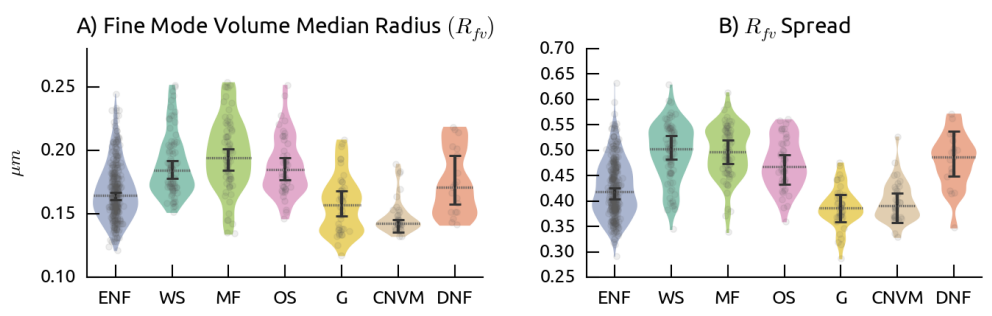

D) Maximum satellite AOT

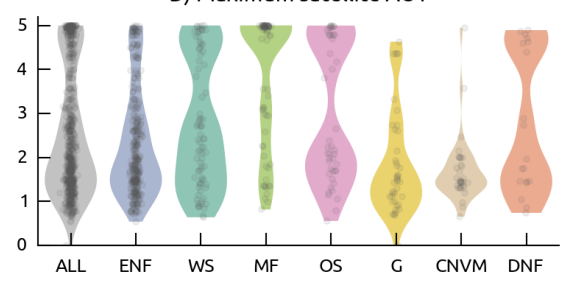

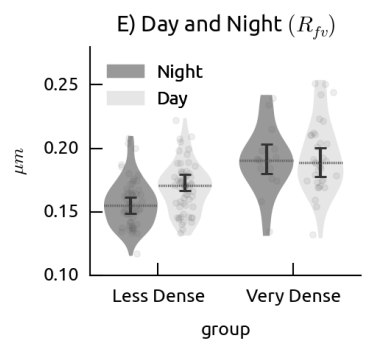

C) Single Scattering Albedo $440 \mathrm{~nm}$

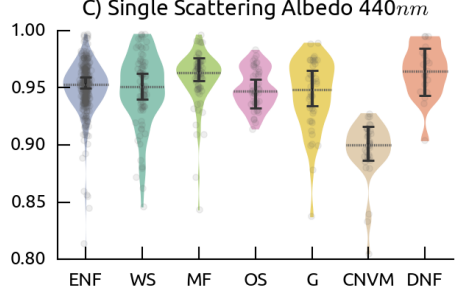

Evergreen Needleleaf Forest (ENF)

Woody Savannas (WS)

Mixed Forest (MF)

Open Shrubland (OS)

Grasslands (G)

Cropland/Natural Vegatation Mosaic (CNVM)

Deciduous Needleleaf Forest (DNF)

- Median

- Individual observations

Figure 5. Optical and microphysical properties of smoke attributed to different land cover types (a-c). Maximum satellite AOT detections along the identified trajectories (d) and fine mode volume radius distributions attributed to less dense (AOT $<3.5)$ and very dense plumes $($ AOT $>3.5)$ emitted during day and night hours $(\mathbf{e})$. Coloured areas indicate kernel density estimates, error bars represent $95 \%$ confidence intervals for median.

that North American fires tend to be high intensity crown burns consuming more fuel per area burned than predominantly surface fires in Eurasian boreal forests. (Wooster and Zhang, 2004; de Groot et al., 2013). The apparent higher proportion of very dense plumes in Eurasia in this study might be caused by the small number of AERONET stations on the continent and thus greater sampling bias. However, our data also indicates that the extreme events tend to occur north of $50^{\circ}$ latitude, and in biomes with lower tree cover density. Thus, it seems unlikely that such events can be explained solely by variability in intensity of crown and surface fuel combustion. The highest proportion of total fuel in boreal regions is contained below ground as organic soils, peat and root material (van Leeuwen et al., 2014). Notably, the highly dense plumes attributed to mixed forest fires include welldocumented (Chubarova et al., 2012) forest and peat bog fires in Russia in the year 2010. During the events AERONET $\mathrm{AOT}(500)$ values as high as 6.4 were recorded in Moscow. This suggests that ground fuel combustion triggered at least some of the 165 extremely concentrated plumes discussed. Such events are probably over-represented in this study, in particular on the Eurasian continent. Nonetheless they comprise at least 12 to $25 \%$ of all AERONET(440) $\geq 0.4$ observations in the region and period studied and require further investigation.

Particle distributions of smoke originating from the land cover type fires discussed indicate distinctiveness in fine mode volume median radius and spread of $R_{\mathrm{fv}}$. Cropland and/or natural vegetation mosaic and grassland emissions tend to show the smallest particles, with median $R_{\mathrm{fv}}$ values $0.143(0.135-0.145)$ and $0.157(0.148-0.168) \mu \mathrm{m}$. Plumes from mixed forests generally contain the largest particles followed by open shrubland emissions having median $R_{\mathrm{fv}}$ val- ues $0.194(0.184-0.2)$ and $0.185(0.176-0.194) \mu \mathrm{m}$ respectively. The most numerous ENF smoke observations typically have particles smaller than the emissions from mixed forests and woody savannas, with determined median $R_{\mathrm{fv}}$ $0.164(0.16-0.167) \mu \mathrm{m}$. A significant difference in $R_{\mathrm{fv}}$ exists comparing less dense and very dense plumes; estimated median $R_{\mathrm{fv}}$ are $0.163(0.16-0.166)$ and $0.191(0.184-0.195) \mu \mathrm{m}$ for the two initial concentration categories. The width of the fine mode particle distribution is positively related to $R_{\mathrm{fv}}$, and classes with larger particles have wider distributions.

These estimates generally agree with published size distributions for various fuel types. Grass fires are reported to emit smaller particles (Reid and Hobbs, 1998) than forest fires (Dubovik et al., 2002). Boreal smoke particles are known to be generally larger $R_{\mathrm{fv}}$ compared to African or Amazon forest emissions (Reid et al., 2005a), but also exhibit high variability in retrieved properties (Eck et al., 2003, 2009). The distinctiveness in particle size distributions attributed to the three forest cover types - ENF, mixed forests and wooded savannas - is particularly interesting. It indicates significant differences in fuels consumed, combustion conditions and fire intensities between these vegetation types which are typically agglomerated under broad extra-tropical or boreal forest definitions. Differences in median $R_{\mathrm{fv}}$ could be partly explained by varying proportions of very dense plumes attributed to these cover types. Wooded savannas, open shrubland and, in particular, mixed forest emissions are dominated by such events. Inferred particle sizes in optically thick plumes are close to some of the largest documented values (Eck et al., 2009), suggesting that they might be produced by smouldering combustion of peat fuels. Accelerated coagulation rates in highly concentrated plumes and higher particle hygroscopicity may increase $R_{\mathrm{fv}}$ even further. Smaller parti- 
cles in ENF could be due to predominantly flaming combustion of crown fuels, inferred lower initial concentrations and lower coagulation rates just after emission.

Notable differences exist in fine mode particle distributions comparing daytime and night-time emissions. Fire radiative power observations indicate a strong diurnal cycle in burning intensity with a peak at around 2-4 pm local time (Ellicott et al., 2009). Results obtained by this study imply that plumes emitted between $12 \mathrm{pm}$ and $10 \mathrm{pm}$ local time tend to have larger particle $f R_{\mathrm{fv}}$ than the ones emitted between $12 \mathrm{pm}$ and $8 \mathrm{am}$ (Fig. 5e). Plumes aged between 12 and $48 \mathrm{~h}$ were compared, expecting higher accuracy in age estimates for such observations, and minimizing very young smoke bias and long-term ageing effects. Although the spread is large and overlaps are substantial, the day and night differences in $R_{\mathrm{fv}}$ are significant for the less concentrated plumes. Daytime and night-time plumes generally have larger particles, with a median $R_{\mathrm{fv}}$ value of 0.17 ( $0.167-$ $0.18) \mu \mathrm{m}$, compared to $0.155(0.148-0.161) \mu \mathrm{m}$ value for night emissions. A very small difference exists in SSA(440) values. Day plumes are only insignificantly more absorbing, estimated median SSA(440) values are 0.948 (0.943-0.956) and $0.956(0.952-0.962)$ for the day and night emissions respectively. Reid et al. (1999) reported larger and less absorbing particles produced at night in Brazil attributed to smouldering combustion. A different diurnal particle size pattern suggests that larger and more intense flaming daytime fires in boreal regions generate larger particles than more smouldering night-time burning.

The differences in optical properties between plumes attributed to the land cover classes considered are subtle. The variability in single scattering albedo and its spectral dependence is small. Inferred median SSA(440) is close to often reported values of 0.95 for boreal regions (Dubovik et al., 2002; Reid et al., 2005b) for all land cover types except for the plumes from cropland and/or natural vegetation mosaic fires, which are more absorbing and have a median SSA(440) value of 0.9 (0.886-0.916). Notably, in this land cover class the lowest SSA(440) corresponds to the smallest median $R_{\mathrm{fv}}$ (Fig. 5). Smoke from mixed forests, with a median SSA(440) value of 0.963 (0.956-0.977), is slightly less absorbing than ENF, wooded savannas and open shrubland emissions which all have median SSA(440) values not significantly different from 0.95 . These differences in absorption magnitude suggest some variability in flaming vs. smouldering combustion ratios and is consistent with observed differences in size distributions. However, there is little to differentiate between the different forest types considered here based solely on optical properties.

\subsection{Ageing effects on particle distributions}

Significant differences exist comparing AERONET retrieved particle size distributions of young and well-aged plumes. Figure 6a shows fine mode volume median radius $\left(R_{\mathrm{fv}}\right)$ plot- ted against the age estimates. Notably, less dense plumes dominate young estimates, while optically thick large plumes are more frequently detected after several days of ageing. Because of the sampling bias and inherent large differences in size distributions between less dense and very concentrated plumes, the ageing effects for the two smoke categories are compared separately. The low number of very old estimates only allow meaningful comparison of plumes of up to 4 days old, and estimates older than $72 \mathrm{~h}$ were pooled together. Distributions of plumes binned into groups per day of ageing indicate a steady increase in median $R_{\mathrm{fv}}$ for the first 3 days, and only slightly larger particles for plumes aged for more than 3 days. A similar pattern is observed for both plume density categories. Plumes in the oldest age category have median $R_{\mathrm{fv}}$ values larger by $0.02(0.009-0.028)$ and 0.022 $(0.012-0.036) \mu \mathrm{m}$ compared to young smoke of up to a day old for the less dense and very dense plumes respectively. This difference would equate to a $\sim 0.007(0.003-0.012) \mu \mathrm{m}$ flat growth rate in median $R_{\mathrm{fv}}$ per day.

The trajectory analysis indicates that in several cases the same plume was transported over more than one AERONET station, allowing to infer changes in plume properties between the two observations. Unfortunately, only 13 of such events were identified preventing a more robust analysis (Fig. 6a). In 10 out of the 13 cases older particles are larger, while three of the pairs suggest a decrease in $R_{\mathrm{fv}}$ between the observations. The median $R_{\mathrm{fv}}$ change rate is $0.0075(-0.001$ to 0.03$) \mu \mathrm{m}$ per day. The estimate agrees well with the growth rate suggested by differences in particle distributions between young and aged plumes. However, it has large confidence intervals due to the low number of paired observations and uncertainty in individual AERONET retrievals.

Published smoke particle growth magnitude and timescales vary and are difficult to compare due to differences in measuring time interval, techniques, sampled fuels, fire size, intensity, combustion phase and smoke age. Rapid increases by as much as $0.08 \mu \mathrm{m}$ have been reported (Hobbs et al., 1996; Abel et al., 2003), suggesting instantaneous $R_{\mathrm{fv}}$ growth rates of $\sim 0.04 \mu \mathrm{m}$ per hour. Reid et al. (2005a) concluded in their review that aged smoke particle distributions typically have $R_{\mathrm{fv}}$ larger by $0.025 \mu \mathrm{m}$. Importantly, most of the particle growth is attributable to condensation and coagulation happens during the first few hours. The AERONET records typically do not include observations of truly fresh smoke within seconds or minutes after the emission. Consequently, our results are for young to well-aged smoke, which is already transformed by the rapid initial growth and has generally large particles. The changes in particle size distributions inferred in this study happen over the course of days, suggesting that in thick continental plumes particles continue to grow. The principle mechanism driving size increase on such timescales is thought to be coagulation (Radke et al., 1995; Reid et al., 1998; Capes et al., 2008). 

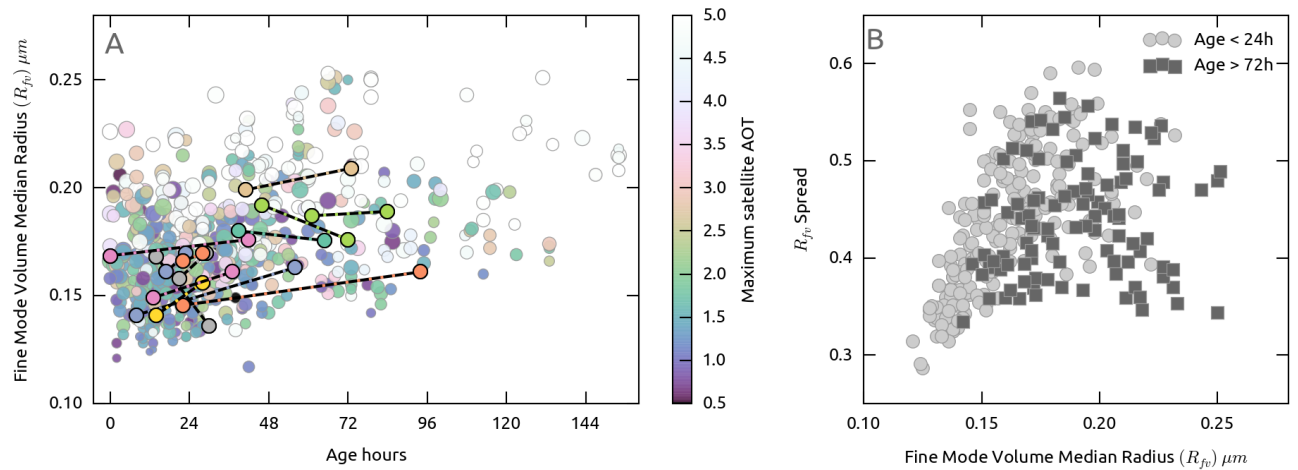

Figure 6. (a) fine mode volume median radius and estimated age. Points joined by lines show identified paired observations. (b) fine mode volume radius against the spread of fine mode volume radius for young and well-aged plumes.
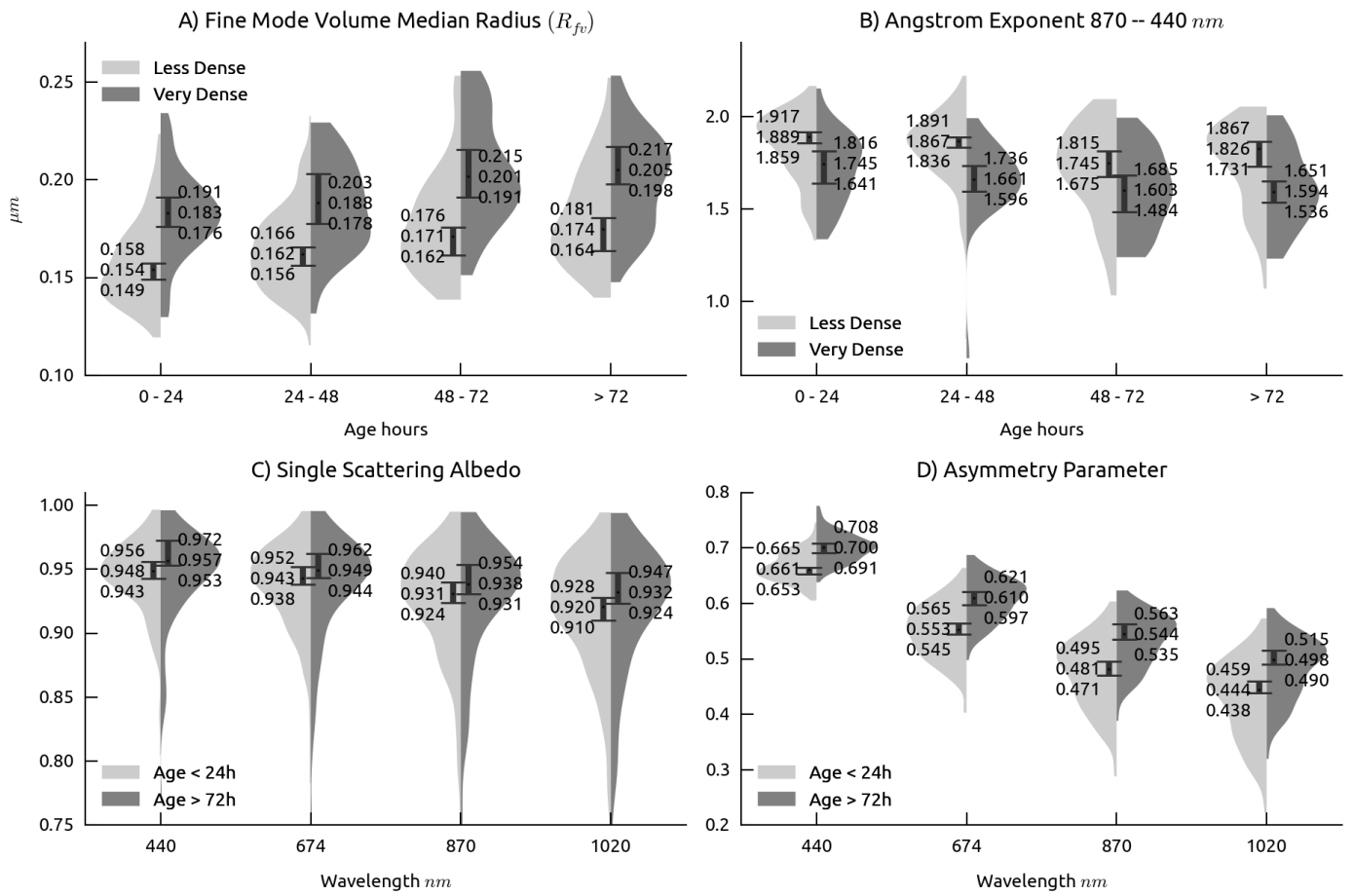

Figure 7. Optical and microphysical properties of young and aged plumes. Less dense $($ AOT $<3.5)$ and very dense $($ AOT $>3.5)$ plumes binned per day of ageing (a-b), plumes under $24 \mathrm{~h}$ old compared with smoke aged for more than $72 \mathrm{~h}$ (c-d). Error bars represent $95 \%$ confidence intervals for median. Numbers on the distributions represent high CI, median value and low CI values.

The spread of $R_{\mathrm{fv}}$ does not exhibit significant dependence on estimated age. Generally, distributions with smaller $R_{\mathrm{fv}}$ tend to have a narrower width (Fig. 6b). The relationship between $R_{\mathrm{fv}}$ and fine mode spread, however, is stronger for young smoke and is not evident for the aged smoke observations. This indicates that while particle sizes increase in ageing plumes, the spread of the fine mode volume radius does not change systematically. Turco and Yu (1999) suggested that condensation narrows the particle distribution, while growth due to coagulation does not alter the width significantly. The lack of significant changes in fine mode spread suggests that the inferred particle growth is attributable to coagulation.

\subsection{Changes in optical properties}

The Ångström exponent (AE) tends to be lower for older plumes (Fig. 7b). In well-aged very dense plumes median AE changes by $-0.15(-0.036$ to -0.26$)$ from a 1.74 (1.64$1.82)$ value for young plumes. The difference is smaller and not significant for the less dense plumes, for which median $\mathrm{AE}$ changes by -0.06 ( 0.002 to -0.15$)$ from median value of 1.89 (1.86-1.92) estimated for young plumes. Decreas- 
ing wavelength dependence of AOT corresponds to inferred particle growth and is an expected result. Changes in median AE, however, are not as consistent as differences in median $R_{\mathrm{fv}}$ between the plume age and density categories. This variability could be due to uncertainties in AERONET inversions, insufficient sample size for some land cover classes, or they could reflect effects of differences in particle chemistry affecting AE besides particle size.

In contrast to particle size distributions and AE, differences in $\operatorname{SSA}(\lambda)$ are only subtle. $\operatorname{SSA}(\lambda)$ is only slightly higher in plumes aged for more than 3 days compared to young smoke (Fig. 7c). The variability is negligibly small between the two plume density categories. Combined median SSA(440) insignificantly increases from a $\sim 0.95$ value for young smoke to $\sim 0.96$ for the oldest plumes. Mie theory predicts that particle radius growth due to coagulation should generally result in smaller absorption and higher scattering efficiency, hence an increase in $\operatorname{SSA}(\lambda)$ (Bond and Bergstrom, 2006). Such an increase in ageing smoke has been observed in Brazil (Reid et al., 1998), West Africa (Abel et al., 2003; Capes et al., 2008), Spain (Calvo et al., 2010) and North America (Eck et al., 2009). Notably, most of the aforementioned studies were analysing inherently more absorbing smoke with typically smaller particles compared to emissions from the sources explored in this study. It is possible that most of the scattering enhancement happens during the rapid evolution phase within a few hours from the emission and thus can not be observed by the method employed in this study. Cropland and/or natural vegetation plumes are significantly more absorbing, but with only 34 estimates a meaningful analysis of ageing effects is not achievable.

The asymmetry parameter is higher in well-aged plumes (Fig. 7d), indicating lower back-scatter due to larger $R_{\mathrm{fv}}$. The change is consistent across the wavelengths and is similar between the smoke concentration groups. For combined plumes at $440 \mathrm{~nm}$ the median asymmetry parameter is higher by $0.038(0.027-0.055)$ in well-aged plumes. At longer wavelengths the asymmetry parameter is lower, but the difference in median values between the young and aged plumes is larger.

\section{Conclusions}

This study presents an analysis of ageing effects on smoke particle size distribution and optical properties in regions associated with large variability in aerosol characteristics. A new method was developed allowing the source and age attribution for AERONET aerosol observations, and applied to data from stations located in or near northern temperate and boreal forests in North America and Asia.

The results show that plume properties vary with the determined source vegetation type as defined by the land cover classification scheme. Notable variability exists not only when comparing emissions from grasslands, croplands and forests, but also different forest types. Plumes from mixed forests are generally the most concentrated and contain the largest particles with a median $R_{\mathrm{fv}} 0.193 \mu \mathrm{m}$, followed by emissions from wooded savannas and shrubland. Smoke attributed to evergreen needleleaf forest fires has lower initial concentrations and exhibit smaller particles than other forest emissions, having median $R_{\mathrm{fv}}$ value $0.164 \mu \mathrm{m}$ which is close to the $R_{\mathrm{fv}}$ values of 0.143 and $0.157 \mu \mathrm{m}$ observed in plumes from cropland and grass fires. These differences appear to be partly influenced by the frequent occurrence of extremely concentrated plumes in some land cover types. Such events tend to have very large particles, and at least in some cases originate from peat fires. Day emissions show significantly larger particles compared to night-time smoke.

Absorption properties do not exhibit significant variability. Estimated median SSA(440) values range from 0.95 to 0.97 for all of the sources considered in this study with the notable exception of cropland and natural vegetation plumes which are substantially more absorbing with $\operatorname{SSA}(440)$ value of 0.9 .

Plumes older than 3 days have higher median $R_{\mathrm{fv}}$ values by $\sim 0.02 \mu \mathrm{m}$ compared to smoke aged for less than a day. This suggests a $\sim 0.007 \mu \mathrm{m}$ increase in $R_{\mathrm{fv}}$ for the first 3 days of ageing. Median growth rate derived from the 13 cases when the same plume was observed at two AERONET stations is remarkably similar $(0.0075 \mu \mathrm{m})$. However it is not significant and highly sensitive to uncertainties in AERONET $R_{\mathrm{fv}}$ retrievals. No significant shift in fine mode spread in well-aged plumes is observed, suggesting that the growth is driven by coagulation.

In contrast to size distributions, smoke $\operatorname{SSA}(\lambda)$ do not differ significantly with plume age. Well-aged plumes are only slightly less absorbing. The Ångström exponent is lower while the asymmetry parameter is higher in older plumes, reflecting the increase in particle $R_{\mathrm{fv}}$.

The method and results presented here allow the microphysical and optical characterisation of particulate emissions from different vegetation types to be improved. Estimated ageing effects provide information on long term particle evolution and active processes in large and dense plumes. These independent estimates are based on a large sample, compare favourably with existing estimates and refine growth rates obtained by different methods.

Acknowledgements. This study was supported by the Natural Environment Research Council (NERC) (Grant NE4/D501177/1) and The Leverhulme Trust (Grant RPG-2014-095). The authors gratefully acknowledge the AERONET team for their effort in establishing and maintaining the network, and the data provision. NOAA Air Resources Laboratory (ARL) for the provision of the HYSPLIT transport and dispersion model. MODIS collection $5.1 \mathrm{M}^{*} \mathrm{D} 05 \_\mathrm{L} 2$ data sets were obtained from the Level 1 and Atmosphere Archive and Distribution System (LAADS) FTP site. Fire Information for Resource Management System (FIRMS) MODIS fire hotspot data was obtained from the NASA Earth Observing System Data and Information System (EOSDIS) 
site. MODIS MCD12C1 land cover type data was downloaded from the Land Processes Distributed Active Archive Center (LP DAAC) site. AATSR_SU version 4.2 data sets were made available under the ESA Aerosol CCI project http://www.esa-aerosol-cci.org.

Edited by: P. Monks

\section{References}

Abel, S. J., Haywood, J. M., Highwood, E. J., Li, J., and Buseck, P. R.: Evolution of biomass burning aerosol properties from an agricultural fire in southern Africa, Geophys. Res. Lett., 30, 1783, doi:10.1029/2003GL017342, 2003.

Akagi, S. K., Craven, J. S., Taylor, J. W. and McMeeking, G. R., Yokelson, R. J., Burling, I. R., Urbanski, S. P., Wold, C. E., Seinfeld, J. H., Coe, H., Alvarado, M. J. and Weise, D. R.: Evolution of trace gases and particles emitted by a chaparral fire in California, Atmos. Chem. Phys., 12, 1397-1421, doi:10.5194/acp-121397-2012,2012

Bauer, S. E., Menon, S., Koch, D., Bond, T. C., and Tsigaridis, K.: A global modeling study on carbonaceous aerosol microphysical characteristics and radiative effects, Atmos. Chem. Phys., 10, 7439-7456, doi:10.5194/acp-10-7439-2010, 2010.

Bevan, S. L., North, P. R., Grey, W. M., Los, S. O., and Plummer, S. E.: Impact of atmospheric aerosol from biomass burning on Amazon dry-season drought, J. Geophys. Res.-Atmos., 114, D09204, doi:10.1029/2008JD011112, 2009.

Bevan, S. L., North, P. R., Los, S. O., and Grey, W. M.: A global dataset of atmospheric aerosol optical depth and surface reflectance from AATSR, Remote Sens. Environ., 116, 199-210, 2012

Bond, T. C. and Bergstrom, R. W.: Light absorption by carbonaceous particles: an investigative review, Aerosol Sci. Tech., 40, 27-67, 2006.

Bond, T. C., Doherty, S. J., Fahey, D. W., Forster, P. M., Berntsen, T., DeAngelo, B. J., Flanner, M. G., Ghan, S., Kärcher, B., Koch, D., Kinne, S., Kondo, Y., Quinn, P. K., Sarofim, M. C., Schultz, M. G., Schulz, M., Venkataraman, C., Zhang, H., Zhang, S., Bellouin, N., Guttikunda, S. K., Hopke, P. K., Jacobson, M. Z., Kaiser, J. W., Klimont, Z., Lohmann, U., Schwarz, J. P., Shindell, D., Storelvmo, T., Warren, S. G., and Zender, C. S.: Bounding the role of black carbon in the climate system: a scientific assessment, J. Geophys. Res.-Atmos., 118, 5380-5552, doi:10.1002/jgrd.50171, 2013.

Calvo, A., Pont, V., Castro, A., Mallet, M., Palencia, C., Roger, J., Dubuisson, P., and Fraile, R.: Radiative forcing of haze during a forest fire in Spain, J. Geophys. Res.-Atmos., 115, D08206, doi:10.1029/2009JD012172, 2010.

Capes, G., Johnson, B., McFiggans, G., Williams, P., Haywood, J., and Coe, H.: Aging of biomass burning aerosols over West Africa: aircraft measurements of chemical composition, microphysical properties, and emission ratios, J. Geophys. Res.Atmos., 113, D00C15, doi:10.1029/2008JD009845, 2008.

Chubarova, N., Nezval', Ye., Sviridenkov, I., Smirnov, A., and Slutsker, I.: Smoke aerosol and its radiative effects during extreme fire event over Central Russia in summer 2010, Atmos. Meas. Tech., 5, 557-568, doi:10.5194/amt-5-557-2012, 2012.
Colarco, P., Schoeberl, M., Doddridge, B., Marufu, L., Torres, O., and Welton, E.: Transport of smoke from Canadian forest fires to the surface near Washington, DC: injection height, entrainment, and optical properties, J. Geophys. Res.-Atmos., 109, D06203, doi:10.1029/2003JD004248, 2004.

Dahlkötter, F., Gysel, M., Sauer, D., Minikin, A., Baumann, R., Seifert, P., Ansmann, A., Fromm, M., Voigt, C., and Weinzierl, B.: The Pagami Creek smoke plume after long-range transport to the upper troposphere over Europe - aerosol properties and black carbon mixing state, Atmos. Chem. Phys., 14, 6111-6137, doi:10.5194/acp-14-6111-2014, 2014.

Damoah, R., Spichtinger, N., Forster, C., James, P., Mattis, I., Wandinger, U., Beirle, S., Wagner, T., and Stohl, A.: Around the world in 17 days - hemispheric-scale transport of forest fire smoke from Russia in May 2003, Atmos. Chem. Phys., 4, 13111321, doi:10.5194/acp-4-1311-2004, 2004.

Damoah, R., Spichtinger, N., Servranckx, R., Fromm, M., Eloranta, E. W., Razenkov, I. A., James, P., Shulski, M., Forster, C., and Stohl, A.: A case study of pyro-convection using transport model and remote sensing data, Atmos. Chem. Phys., 6, 173185, doi:10.5194/acp-6-173-2006, 2006.

de Groot, W. J., Cantin, A. S., Flannigan, M. D., Soja, A. J., Gowman, L. M., and Newbery, A.: A comparison of Canadian and Russian boreal forest fire regimes, Forest Ecol. Manag., 294, 23 34,2013.

de Leeuw, G., Holzer-Popp, T., Bevan, S., Davies, W., Descloitres, J., Grainger, R. G., Griesfeller, J., Heckel, A., Kinne, S., Klüser, L., Kolmonen, P., Litvinov, P., Martynenko, D., North, P. J. R., Ovigneur, B., Pascal, N., Poulsen, C., Ramon, D., Schulz, M., Siddans, R., Sogacheva, L., Tanré, D., Thomas, G. E., Virtanen, T. H., von Hoyningen Huene, W., Vountas, M., and Pinnock, S.: Evaluation of seven European aerosol optical depth retrieval algorithms for climate analysis, Remote Sens. Environ., 295-315 doi:10.1016/j.rse.2013.04.023, 2013.

Dirksen, R. J., Folkert Boersma, K., De Laat, J., Stammes, P., Van Der Werf, G. R., Val Martin, M., and Kelder, H. M.: An aerosol boomerang: rapid around-the-world transport of smoke from the December 2006 Australian forest fires observed from space, J. Geophys. Res.-Atmos., 114, D21201, doi:10.1029/2009JD012360, 2009.

Draxler, R. and Rolph, G.: HYSPLIT (HYbrid Single-Particle Lagrangian Integrated Trajectory) model access via NOAA ARL READY website, available at: http://www.arl.noaa.gov/ready/ hysplit4.html (last access: 17 December 2014), NOAA Air Resources Laboratory, Silver Spring, 2003.

Dubovik, O. and King, M. D.: A flexible inversion algorithm for retrieval of aerosol optical properties from Sun and sky radiance measurements, J. Geophys. Res.-Atmos., 105, 20673-20696, 2000.

Dubovik, O., Smirnov, A., Holben, B., King, M., Kaufman, Y., Eck, T., and Slutsker, I.: Accuracy assessments of aerosol optical properties retrieved from Aerosol Robotic Network (AERONET) Sun and sky radiance measurements, J. Geophys. Res.-Atmos., 105, 9791-9806, 2000.

Dubovik, O., Holben, B., Eck, T. F., Smirnov, A., Kaufman, Y. J., King, M. D., Tanre, D., and Slutsker, I.: Variability of absorption and optical properties of key aerosol types observed in worldwide locations, J. Atmos. Sci., 59, 590-608, 2002. 
Dubovik, O., Sinyuk, A., Lapyonok, T., Holben, B. N., Mishchenko, M., Yang, P., Eck, T. F., Volten, H., Muñoz, O., Veihelmann, B., van der Zande, W. J., Leon, J.-F., Sorokin, M., and Slutsker, I.: Application of spheroid models to account for aerosol particle nonsphericity in remote sensing of desert dust, J. Geophys. Res.Atmos., 111, D11208, doi:10.1029/2005JD006619, 2006.

Dubovik, O., Herman, M., Holdak, A., Lapyonok, T., Tanré, D., Deuzé, J. L., Ducos, F., Sinyuk, A., and Lopatin, A.: Statistically optimized inversion algorithm for enhanced retrieval of aerosol properties from spectral multi-angle polarimetric satellite observations, Atmos. Meas. Tech., 4, 975-1018, doi:10.5194/amt-4975-2011, 2011.

Eck, T., Holben, B., Reid, J., O’Neill, N., Schafer, J., Dubovik, O., Smirnov, A., Yamasoe, M., and Artaxo, P.: High aerosol optical depth biomass burning events: a comparison of optical properties for different source regions, Geophys. Res. Lett., 30, 2035, doi:10.1029/2003GL017861, 2003.

Eck, T. F., Holben, B. N., Reid, J. S., Sinyuk, A., Hyer, E. J., O'Neill, N. T., Shaw, G. E., Vande Castle, J. R., Chapin, F. S., Dubovik, O., Smirnov, A., Vermote, E., Schafer, J. S., Giles, D., Slutsker, I., Sorokine, M., and Newcomb, W. W.: Optical properties of boreal region biomass burning aerosols in central Alaska and seasonal variation of aerosol optical depth at an Arctic coastal site, J. Geophys. Res.-Atmos., 114, D11201, doi:10.1029/2008JD010870, 2009.

Ellicott, E., Vermote, E., Giglio, L., and Roberts, G.: Estimating biomass consumed from fire using MODIS FRE, Geophys. Res. Lett., 36, 1-5, doi:10.1029/2009GL038581, 2009.

Ester, M., Kriegel, H.-P., Sander, J., and Xu, X.: A density-based algorithm for discovering clusters in large spatial databases with noise, in: Proceedings of the Second International Conference on Knowledge Discovery and Data Mining (KDD-96), edited by: Simoudis, E., Han, J., and Fayyad, U., 226-231, Menlo Park, CA, AAAI Press, 1996.

Giglio, L., Descloitres, J., Justice, C. O., and Kaufman, Y. J.: An enhanced contextual fire detection algorithm for MODIS, Remote Sens. Environ., 87, 273-282, 2003.

Giles, D. M., Holben, B. N., Eck, T. F., Sinyuk, A., Smirnov, A., Slutsker, I., Dickerson, R., Thompson, A., and Schafer, J.: An analysis of AERONET aerosol absorption properties and classifications representative of aerosol source regions, J. Geophys. Res.-Atmos., 117, D17203, doi:10.1029/2012JD018127, 2012.

Haywood, J., Francis, P., Dubovik, O., Glew, M., and Holben, B.: Comparison of aerosol size distributions, radiative properties, and optical depths determined by aircraft observations and Sun photometers during SAFARI 2000, J. Geophys. Res.-Atmos., 108, 8471, doi:10.1029/2002JD002250, 2003.

Hobbs, P. V., Reid, J. S., Herring, J. A., Nance, J. D., and Weiss, R. E.: Particle and Trace-Gas Measurements in the Smoke from Prescribed Burns of Forest Products in the Pacific Northwest, in: Biomass Burning and Global Change, Vol. 1, edited by: Levine, J. S., MIT Press, New York, 1006, 697-715, 1996.

Holben, B., Eck, T., Slutsker, I., Tanre, D., Buis, J., Setzer, A., Vermote, E., Reagan, J., Kaufman, Y., Nakajima, T., Lavenu, F., Jankowiak, I., and Smirnov, A.: AERONET a federated instrument network and data archive for aerosol characterization, Remote Sens. Environ., 66, 1-16, 1998.

Holben, B., Eck, T., Slutsker, I., Smirnov, A., Sinyuk, A., Schafer, J., Giles, D., and Dubovik, O.: AERONET's version 2.0 quality assurance criteria, in: Asia-Pacific Remote Sensing Symposium, Goa, India, 13-17 November 2006, 6408, 2006.

Holzer-Popp, T., de Leeuw, G., Griesfeller, J., Martynenko, D., Klüser, L., Bevan, S., Davies, W., Ducos, F., Deuzé, J. L., Graigner, R. G., Heckel, A., von Hoyningen-Hüne, W., Kolmonen, P., Litvinov, P., North, P., Poulsen, C. A., Ramon, D., Siddans, R., Sogacheva, L., Tanre, D., Thomas, G. E., Vountas, M., Descloitres, J., Griesfeller, J., Kinne, S., Schulz, M., and Pinnock, S.: Aerosol retrieval experiments in the ESA Aerosol_cci project, Atmos. Meas. Tech., 6, 1919-1957, doi:10.5194/amt-61919-2013, 2013.

Hyer, E. J. and Reid, J. S.: Baseline uncertainties in biomass burning emission models resulting from spatial error in satellite active fire location data, Geophys. Res. Lett. 36, 1944-8007, doi:10.1029/2008GL036767, 2009.

Jacobson, M. Z.: Strong radiative heating due to the mixing state of black carbon in atmospheric aerosols, Nature, 409, 695-697, 2001.

Janhäll, S., Andreae, M. O., and Pöschl, U.: Biomass burning aerosol emissions from vegetation fires: particle number and mass emission factors and size distributions, Atmos. Chem. Phys., 10, 1427-1439, doi:10.5194/acp-10-1427-2010, 2010.

Johnson, B., Christopher, S., Haywood, J., Osborne, S., McFarlane, S., Hsu, C., Salustro, C., and Kahn, R.: Measurements of aerosol properties from aircraft, satellite and ground-based remote sensing: a case-study from the Dust and Biomass-burning Experiment (DABEX), Q. J. Roy. Meteor. Soc., 135, 922-934, 2009.

Johnston, F. H., Henderson, S. B., Chen, Y., Randerson, J. T., Marlier, M., DeFries, R. S., Kinney, P., Bowman, D. M., and Brauer, M.: Estimated global mortality attributable to smoke from landscape fires, Environ. Health Persp., 120, 695-701, 2012.

Kahn, R. A., Chen, Y., Nelson, D. L., Leung, F.-Y., Li, Q., Diner, D. J., and Logan, J. A.: Wildfire smoke injection heights: two perspectives from space, Geophys. Res. Lett., 35, L04809, doi:10.1029/2007GL032165, 2008.

Kahn, R. A., Nelson, D. L., Garay, M. J., Levy, R. C., Bull, M. A., Diner, D. J., Martonchik, J. V., Paradise, S. R., Hansen, E. G., and Remer, L. A.: MISR aerosol product attributes and statistical comparisons with MODIS, IEEE T. Geosci. Remote, 47, 40954114, 2009.

Kasischke, E. S., Williams, D., and Barry, D.: Analysis of the patterns of large fires in the boreal forest region of Alaska, Int. J Wildland Fire, 11, 131-144, 2002.

Kaufman, Y. J. and Tanre, D.: Algorithm for remote sensing of tropospheric aerosol from MODIS, NASA MODIS Algorithm Theoretical Basis Document, Goddard Space Flight Center,Greenbelt, Md, 85 pp., 1998.

Kinne, S., Lohmann, U., Feichter, J., Schulz, M., Timmreck, C., Ghan, S., Easter, R., Chin, M., Ginoux, P., Takemura, T., Tegen, I., Koch, D., Herzog, M., Penner, J., Pitari, G., Holben, B., Eck, T., Smirnov, A., Dubovik, O., Slutsker, I., Tanre, D., Torres, O., Mishchenko, M., Geogdzhayev, I., Chu, D. A., and Kaufman, Y.: Monthly averages of aerosol properties: a global comparison among models, satellite data, and AERONET ground data, J. Geophys. Res.-Atmos., 108, 4634, doi:10.1029/2001JD001253, 2003. 
Koch, D., Schulz, M., Kinne, S., McNaughton, C., Spackman, J. R., Balkanski, Y., Bauer, S., Berntsen, T., Bond, T. C., Boucher, O., Chin, M., Clarke, A., De Luca, N., Dentener, F., Diehl, T., Dubovik, O., Easter, R., Fahey, D. W., Feichter, J., Fillmore, D., Freitag, S., Ghan, S., Ginoux, P., Gong, S., Horowitz, L., Iversen, T., Kirkevåg, A., Klimont, Z., Kondo, Y., Krol, M., Liu, X., Miller, R., Montanaro, V., Moteki, N., Myhre, G., Penner, J. E., Perlwitz, J., Pitari, G., Reddy, S., Sahu, L., Sakamoto, H., Schuster, G., Schwarz, J. P., Seland, Ø., Stier, P., Takegawa, N., Takemura, T., Textor, C., van Aardenne, J. A., and Zhao, Y.: Evaluation of black carbon estimations in global aerosol models, Atmos. Chem. Phys., 9, 9001-9026, doi:10.5194/acp-9-9001-2009, 2009.

Kokhanovsky, A. A., Deuzé, J. L., Diner, D. J., Dubovik, O., Ducos, F., Emde, C., Garay, M. J., Grainger, R. G., Heckel, A., Herman, M., Katsev, I. L., Keller, J., Levy, R., North, P. R. J., Prikhach, A. S., Rozanov, V. V., Sayer, A. M., Ota, Y., Tanré, D., Thomas, G. E., and Zege, E. P.: The inter-comparison of major satellite aerosol retrieval algorithms using simulated intensity and polarization characteristics of reflected light, Atmos. Meas. Tech., 3, 909-932, doi:10.5194/amt-3-909-2010, 2010.

Langmann, B., Duncan, B., Textor, C., Trentmann, J., and van der Werf, G. R.: Vegetation fire emissions and their impact on air pollution and climate, Atmos. Environ., 43, 107-116, 2009.

Lee, K. W. and Chen, H.: Coagulation Rate of Polydisperse Particles, Aerosol Sci. Tech., 3, 327-334, 1984.

Lee, J., Kim, J., Song, C., Kim, S., Chun, Y., Sohn, B., and Holben, B.: Characteristics of aerosol types from AERONET sunphotometer measurements, Atmos. Environ., 44, 3110-3117, 2010.

Levy, R. C., Remer, L. A., Tanre, D., Mattoo, S., and Kaufman, Y. J.: Algorithm for Remote Sensing of Tropospheric Aerosol over Dark Targets from MODIS: Collections 005 and 051: Revision 2, Feb 2009, available at: http://modis-atmos.gsfc.nasa.gov/_docs/ ATBD_MOD04_C005_rev2.pdf (last access: 24 February 2015), 2009

Levy, R. C., Remer, L. A., Kleidman, R. G., Mattoo, S., Ichoku, C., Kahn, R., and Eck, T. F.: Global evaluation of the Collection 5 MODIS dark-target aerosol products over land, Atmos. Chem. Phys., 10, 10399-10420, doi:10.5194/acp-10-10399-2010, 2010.

Livingston, J. M., Redemann, J., Shinozuka, Y., Johnson, R., Russell, P. B., Zhang, Q., Mattoo, S., Remer, L., Levy, R., Munchak, L., and Ramachandran, S.: Comparison of MODIS $3 \mathrm{~km}$ and $10 \mathrm{~km}$ resolution aerosol optical depth retrievals over land with airborne sunphotometer measurements during ARCTAS summer 2008, Atmos. Chem. Phys., 14, 2015-2038, doi:10.5194/acp-142015-2014, 2014.

Loveland, T. and Belward, A.: The IGBP-DIS global $1 \mathrm{~km}$ land cover data set, DISCover: first results, Int. J. Remote Sens., 18, 3289-3295, 1997.

Magi, B. I. and Hobbs, P. V.: Effects of humidity on aerosols in southern Africa during the biomass burning season, J. Geophys. Res.-Atmos., 108, 2156-2202, 2003

Myhre, G., Samset, B. H., Schulz, M., Balkanski, Y., Bauer, S., Berntsen, T. K., Bian, H., Bellouin, N., Chin, M., Diehl, T., Easter, R. C., Feichter, J., Ghan, S. J., Hauglustaine, D., Iversen, T., Kinne, S., Kirkevåg, A., Lamarque, J.-F., Lin, G., Liu, X., Lund, M. T., Luo, G., Ma, X., van Noije, T., Penner, J. E., Rasch, P. J., Ruiz, A., Seland, Ø., Skeie, R. B.,
Stier, P., Takemura, T., Tsigaridis, K., Wang, P., Wang, Z., Xu, L., Yu, H., Yu, F., Yoon, J.-H., Zhang, K., Zhang, H., and Zhou, C.: Radiative forcing of the direct aerosol effect from AeroCom Phase II simulations, Atmos. Chem. Phys., 13, 18531877, doi:10.5194/acp-13-1853-2013, 2013.

Nakajima, T., Higurashi, A., Takeuchi, N., and Herman, J. R.: Satellite and ground-based study of optical properties of 1997 Indonesian forest fire aerosols, Geophys. Res. Lett., 26, 2421-2424, 1999.

North, P. R.: Estimation of aerosol opacity and land surface bidirectional reflectance from ATSR-2 dual-angle imagery: operational method and validation, J. Geophys. Res.-Atmos., 107, AAC-4-1, doi:10.1029/2000JD000207, 2002.

O’Neill, N., Eck, T., Holben, B., Smirnov, A., Royer, A., and Li, Z.: Optical properties of boreal forest fire smoke derived from Sun photometry, J. Geophys. Res.-Atmos., 107, AAC-6-1, doi:10.1029/2001JD000877, 2002.

Radke, L. F., Hegg, A, S., Hobbs, P. V., and Penner, J. E.: Effects of aging on the smoke from a large forest fire, Atmos. Res., 38, 315-332, 1995.

Reid, J. S. and Hobbs, P. V.: Physical and optical properties of young smoke from individual biomass fires in Brazil, J. Geophys. Res.Atmos., 103, 32013-32030, 1998.

Reid, J. S., Hobbs, P. V., Ferek, R. J., Blake, D. R., Martins, J. V., Dunlap, M. R., and Liousse, C.: Physical, chemical, and optical properties of regional hazes dominated by smoke in Brazil, J. Geophys. Res.-Atmos., 103, 32059-32080, 1998.

Reid, J. S., Eck, T. F., Christopher, S. A., Hobbs, P. V., Holben, B.: Use of the Angstrom exponent to estimate the variability of optical and physical properties of aging smoke particles in Brazil, J. Geophys. Res.-Atmos., 104, 27472-27489, doi:10.1029/1999JD900833, 1999.

Reid, J. S., Koppmann, R., Eck, T. F., and Eleuterio, D. P.: A review of biomass burning emissions part II: intensive physical properties of biomass burning particles, Atmos. Chem. Phys., 5, 799825, doi:10.5194/acp-5-799-2005, 2005a.

Reid, J. S., Eck, T. F., Christopher, S. A., Koppmann, R., Dubovik, O., Eleuterio, D. P., Holben, B. N., Reid, E. A., and Zhang, J.: A review of biomass burning emissions part III: intensive optical properties of biomass burning particles, Atmos. Chem. Phys., 5, 827-849, doi:10.5194/acp-5-827-2005, 2005b.

Rissler, J., Vestin, A., Swietlicki, E., Fisch, G., Zhou, J., Artaxo, P., Andreae, M. O.: Size distribution and hygroscopic properties of aerosol particles from dry-season biomass burning in Amazonia, Atmos. Chem. Phys., 6, 471-491, doi:10.5194/acp-6-471-2006, 2006.

Sayer, A. M., Hsu, N. C., Eck, T. F., Smirnov, A., and Holben, B. N.: AERONET-based models of smoke-dominated aerosol near source regions and transported over oceans, and implications for satellite retrievals of aerosol optical depth, Atmos. Chem. Phys., 14, 11493-11523, doi:10.5194/acp-14-11493-2014, 2014.

Stocks, B. J., Mason, J. A., Todd, J. B., Bosch, E. M., Wotton, B. M., Amiro, B. D., Flannigan, M. D., Hirsch, K. G., Logan, K. A., Martell, D. L., and Skinner, W. R.: Large forest fires in Canada, 1959-1997, J. Geophys. Res.-Atmos., 107, 8149, doi:10.1029/2001JD000484, 2002.

Torres, O., Tanskanen, A., Veihelmann, B., Ahn, C., Braak, R., Bhartia, P. K., Veefkind, P., and Levelt, P.: Aerosols and surface UV products from Ozone Monitoring Instrument obser- 
vations: an overview, J. Geophys. Res.-Atmos., 112, D24S47, doi:10.1029/2007JD008809, 2007.

Turco, R. P. and Yu, F.: Particle size distributions in an expanding plume undergoing simultaneous coagulation and condensation, J. Geophys. Res.-Atmos., 104, 19227-19241, doi:10.1029/1999JD900321, 1999.

Val Martin, M., Logan, J. A., Kahn, R. A., Leung, F.-Y., Nelson, D. L., and Diner, D. J.: Smoke injection heights from fires in North America: analysis of 5 years of satellite observations, Atmos. Chem. Phys., 10, 1491-1510, doi:10.5194/acp-10-14912010, 2010.

van der Werf, G. R., Randerson, J. T., Giglio, L., Collatz, G. J., Mu, M., Kasibhatla, P. S., Morton, D. C., DeFries, R. S., Jin, Y., and van Leeuwen, T. T.: Global fire emissions and the contribution of deforestation, savanna, forest, agricultural, and peat fires (1997-2009), Atmos. Chem. Phys., 10, 11707-11735, doi:10.5194/acp-10-11707-2010, 2010. van Leeuwen, T. T., van der Werf, G. R., Hoffmann, A. A., Detmers, R. G., Rücker, G., French, N. H. F., Archibald, S., Carvalho Jr., J. A., Cook, G. D., de Groot, W. J., Hély, C., Kasischke, E. S., Kloster, S., McCarty, J. L., Pettinari, M. L., Savadogo, P., Alvarado, E. C., Boschetti, L., Manuri, S., Meyer, C. P., Siegert, F., Trollope, L. A., Trollope, W. S. W.: Biomass burning fuel consumption rates: a field measurement database, Biogeosciences, 11, 7305-7329, doi:10.5194/bg-11-7305-2014, 2014.

Wooster, M. J. and Zhang, Y. H.: Boreal forest fires burn less intensely in Russia than in North America, Geophys. Res. Lett., 31, doi:10.1029/2004GL020805, 2004. 